\title{
Technology Transfer In Indonesia And China: A Comparative Study
}

\author{
Abdul Thalib \\ Fakultas Hukum Universitas Islam Riau \\ JIn. Kaharudin Nasution No. 113 Kota Pekanbaru Riau 28284 \\ thalib_abd7164@yahoo.com
}

\begin{abstract}
The problems in this study: first, whether the patent system in Indonesia and China is effective for technology transfer? Second, what are the roles of the Chinese and Indonesia government for technology transfer? This study uses a normative legal research. The results of the research concluded that first, there are no special regulations in Indonesia regulating the transfer of technology. Some policies are contradict to each other and are directed to meet the needs of special parts of industry. While in China, the rules governing the transfer of technology experiences some changes along with China's accession to WTO. Second, the Indonesian government has attempted to use some performance requirements in the regulation of foreign investment for the faster transfer effect from technology. However, the existing legislation is weak or not enforced, and there are no special incentives to encourage FDI to upgrade local technological capabilities.
\end{abstract}

Key word: Technology Transfer, Indonesia, China

\begin{abstract}
Abstrak
Permasalahan dalam penelitian ini, pertama, apakah sistem paten Indonesia dan China efektif untuk transfer teknologi? Kedua, apa peran pemerintah dan China Indonesia untuk transfer teknologi? Penelitian ini menggunakan penelitian hukum normatif. Hasil penelitian menyimpulkan, pertama, tidak ada peraturan khusus di Indonesia yang mengatur tentang transfer teknologi. Beberapa kebijakan bertentangan satu sama lain dan diarahkan untuk memenuhi kebutuhan bagian khusus industri. Sedangkan di China, peraturan yang mengatur transfer teknologi mengalami perubahan seiring dengan aksesi China ke WTO. Kedua, Pemerintah Indonesia telah berusaha untuk menggunakan beberapa persyaratan kinerja dalam peraturan investasi asing untuk efek transfer yang lebih cepat dari teknologi. Namun, peraturan yang ada sangat lemah atau tidak ditegakkan, serta tidak ada insentif khusus untuk mendorong FDI yang meng-upgrade kemampuan teknologi lokal.
\end{abstract}

Key word: Transfer Technologi, Indonesia, China. 


\section{Introduction}

The 2011 marked the 50th anniversary of the technology transfer (TT) debates at the international level. $\mathrm{T} \mathrm{T}$ was first tabled as an international issue in 1961, with a request to the United Nations Secretary General by some developing countries that studies be commissioned to ascertain the role of international treaties in promoting intellectual property rights (IPRs) protection in developing countries (DCs). With time, the debate has grown in proportion and permeated different processes and institutions. Looking back, the subject has increasingly gained prominence because developing countries felt both the need to revise international treaties dealing with intellectual property (IP), and to ensure that there is a specific framework on TT that promoted their access to existing technologies. Targeted efforts to achieve these ends failed to materialize by the mid-1980s. Despite the failure of those efforts, the fundamental issues raised fifty years ago still remain relevant today and continue to influence and polarize international debates. ${ }^{1}$

In the span of these fifty years, many development occurred in the international political economy of TT negotiations. At the same time, our understanding of the processes and institutions that influence technological change has evolved. From a situation where we had little understanding of technological change and how it occurs, ${ }^{2}$ immense progress has been made over the past five decades to highlight its determinants within and amongst countries at different stages of development. Not only do we have a better understanding of technology and its sources of origin, but we have also moved towards deciphering the critical relationship between technology, innovation and development, both in terms of empirical evidence and policy making.

What we know up until now can be summarised as a set of stylized facts. First, technology - particularly access to existing technology - plays a central role in catch-up growth: a process of closing the gap between those countries that

${ }^{1}$ See P. Gehl Sampath, P. Roffe (2012) - Unpacking the International Technology Transfer Debate: Fifty Years and Beyond, International Centre for Trade and Sustainable Development (ICTSD), Issue Paper No. 36, International Environment House 2, 7 Chemin de Balexert, 1219 Geneva, Switzerland, p. 1.

${ }^{2}$ Rosenberg N, Inside the Black Box: Technology and Economics (Cambridge Univ Press, Cambridge), 1983, p 320 . 
produce new knowledge (industrial countries) and others that are learning to create products and processes that are new to their contexts but not necessarily to the world at large. ${ }^{3 S e c o n d}$, technological change of this kind is often not about innovating at the frontier, but rather about how the structure of production can be changed to achieve higher levels of productivity. This makes technological change a fundamental component of capital accumulation and structural change within countries. Third, despite the fact that a large amount of technology is already available in the public domain, accessing these technologies and channelling them into processes of knowledge accumulation and innovation within countries is neither automatic nor costless. ${ }^{4}$ Using already available technology in the public domain requires the existence of technological capacity amongst actors.

Despite these insights on the important role of technological change for development, the world has been witnessing the emergence of a widening technological divide not only between the technologically developed and the developing world, but also among the developing countries themselves. Technological divergence among developing countries is increasing with time, especially now that several developing countries are well on their way to catching up. ${ }^{5}$ While some countries have been relatively successful, there are still many developing countries for whom technological marginalization is a recurrent reality. ${ }^{6}$

${ }^{3}$ Ocampo, J.A., Sundaram, J.K. \& Khan, S., Policy matters: economic and social policies tosustain equitable development, Zed Books, 2007, pp. 1-24.

${ }^{4}$ Gerschenkron, A., 1962. Economic backwardness in bistorical perspective: a book of essays, Belknap Press of Harvard University Press, pp. 360-362. Gerschenkron notes that for the "latecomers", there exist untapped opportunities offered by globalization through which they can access unprecedented degrees of information and knowledge.

${ }^{5}$ United Nations Conference on Trade and Development, 2012. Innovation, Technology and Innovation Report: Technology and South-South Collaboration, UNCTAD New York and Geneva. Here UNCTAD views that Economic catch up is commonly understood as the process of closing the gap between DCs and their industrial counterparts.

${ }^{6}$ Ocampo, J.A. \& Vos, R., Uneven economic development, United Nations Publications, 2009, pp. 58-74. Ocampo $\&$ Vos in this context note that already as of 2000 , DCs accounted for $50 \%$ of all global low value manufactures. While participation in medium technology manufactures increased, this was concentrated in the South East Asian and Latin American DCs and high technology manufacturing was accounted for mostly by the South East Asian DCs (including China). 


\section{Statements of Problems}

Based on the background which is mentioned previously, the following questions are closely examimed. Firstly, whether the Indonesian Patents system and China is effective for the technology transfer? Secondly, how is the role of Indonesian government and China for the technology transfer?

\section{Objective of the Research}

The objective of the research, as followed: firstly, to analyze the effectiveness of the Indonesian Patents system and China for the technology transfer. Secondlyto analyze the role of Indonesian government and China for the technology transfer.

\section{Research Method}

The research method employed in this study is predominantly normative legal research, focusing on library research, using two approaches, namely statutory approach and comparative approach. Relevant articles, books, local and international law reports, reviews, conference and seminar papers constituted the main source of information for this study. Among many factors to assists in providing an appropriate level of (TT), there are in general two ways of getting foreign technology transferred to developing countries: its sale to local enterprises by licensing (patented and unpatented know-how) and its transfer by means of direct investment. This study assesses the adequacy of TT in Indonesia and China, not only under the statutory Patent Laws, provided by the Indonesian Patents Act 2001, Patent Law of the People's Republic of China 2008-12-27, the rules governing TT in China: (i) Regulation on Technology Import and Export Administration of the People's Republic of China, promulgated by the State Council and come into force January 1, 2002; (ii) Administrative Measures on Registration of Technology Import and Export Contracts, promulgated by the 'ex' MOFTEC now MOFCOM, December 30, 2001 in force January 1, 2002; (iii) Administrative Measures on Import of Prohibited or Restricted Technology, promulgated by MOFCOM, as well as (iv) Administrative 
Measures for Export-Prohibited Technology or Export Restricted Technology), but also from both the government policies. Throughout this study, internationally reported patent agreements will be resorted to wherever possible, to explain the various aspects and the roles of TT under discussion.

\section{Discussion and Result}

\section{Indonesian Regulations}

\section{Patents Law No. 14 of 2001}

In Indonesia, a patent is a temporary monopoly granted by the State in respect of an invention. The owner of a patent, the patentee, shall have exclusive rights and monopoly to exploit or use commercially his patent individually or by giving his consent to other persons to make, sell, lease, deliver, use, supply for sale or lease or delivery of the products for which patenhas been granted. ${ }^{7}$ He may transfer any one or more of these rights either wholly or partly to any other person. ${ }^{8}$ He can also licence its use on his freedom to deal with the patent completely as he wishes. ${ }^{9}$ It is different withsome fields of property however, there are certain limitations on his freedom to deal with the patent completely as he wishes.

Among many factors to assists in providing an appropriate level of TT as indicated above, there are in general two ways of getting foreign technology transferred to DCs: its sale to local enterprises by licensing (patented and unpatented know-how) and its transfer by means of direct investment.

\section{Licences of Rights}

With regard to licence the patentee shall be entitled to give it to another person pursuant to a licence agreement. ${ }^{10}$ The conditions of the licence including the amount of remuneration payable to the patentee (sometimes it is called royalties), is determined in the absence of agreement, by an authority designated

${ }^{7}$ See Article 16 of the Indonesian Patents Law, No. 14 of 2001.

${ }^{8}$ See Article 66 of the Patents Law, 2001.

${ }^{9}$ See Article 69 of the Patents Law, 2001.

${ }^{10}$ See Article 70 of the Patents Law, 2001. 
by the law for this purpose. Moreover, unless otherwise agreed, a patent holder may continue to perform by himself or give a licence to any other third parties to perform the acts referred to in Article 16, which shall be effective during the term of the licence.

This system may be specially attractive to DCs because once a patent is thrown open to licence of right, it will no longer depend on the will of the owner of the patent whether the patent will be exploited in the country, anybody can obtain a licence and on the basis of that licence work the patented invention in the country. But this system has also been criticised that, "the disadvantages of this system is that prosective licensees hesitate to obtain such a non-exclusive licence since competitors can obtain the same at any time. ${ }^{11}$

A licence may be expressed, implied or statutory, it may exclusive, nonexclusive or limited. An exclusive licence is defined under Article 70. Such a licence excludes all other persons including the patentee from the right to use the invention. In regard to a limited licence the limitation may arise as to persons, place, time, use, manufacture and sale. An express licence is one in which the permission to use the patent is given in experts terms. Certain presumptions as to term are provided in Article 69 (2). The licence must presumbly be in writing and to be effective must be registered. ${ }^{12}$

The agreement between the parties concerned must be reduced to the form of a document embodying all the terms and conditions governing their rights and obligations. An application for registration of such document must be registered to the Directorate General of IPRs which shall be recorded and published, with the payment of a fee. Where a licensing agreement is not recorded, said licensing agreement will not have legal effects on a third party. ${ }^{13}$

Furthermore, under Article 71 however, excludes certain clauses from such licences, declaring them to be invalid. The two sorts of clauses are: (i) provision which are directly or indirectly detrimental to the Indonesian economy, and (ii) certain limitations obstructing the capability of the Indonesian people to master and

${ }^{11}$ See Stephen P. Ladas, "Patents, Trademarks and Related Rights: National and International Protection", Harvard University Press, Cambridge, 1975, p. 429.

${ }^{12}$ See Article 72 of the Patents Law, 2001.

${ }^{13}$ Ibid. 
develop the technology generally connected with the patented invention, and particularly the invention for which the patent has been granted.

As far as regulations system on the TT in Indonesia is concerned, apart from Patents Law, 2001 as indicated above, under Articles 11 and 12 Investment Law, No. 25 of 2007 mentioned that:"Enterprises with foreign capital are obliged to arrange and/or to provide facilities for training and education at home or abroad for Indonesian nationals in an organised way and with a set purpose in order that the alien employees may gradually be substituted by Indonesian ones". In addition, the activity program may be organised by the employers or third-party services may be utilized. ${ }^{14}$ The non performance of this obligation results in employers employing foreign worker(s) to pay a compulsory educational and training contribution. Such contributions will be used to fund the Government's manpower education and training. ${ }^{15}$ Beside it, in the oil and gas sector, contractors of oil and gas production sharing contracts are required to provide an educational and training program for all Indonesian employees. ${ }^{16}$ On this subject the Elucidation of the Oil and Gas Law No. 22 of 2001 does not give further explanation.

It should be noted however, that the General Policy towards the skill problem of Indonesian national manpower is, that efforts should be made to enhance knowledge, improve skill, augment the ability to organise and manage. In pursuance of this General Policy we may emphasize that within the framework of mineral oil and gas mining, the above mentioned efforts should also be made by the Government, i.e., the State Oil Enterprise.

On the one hand, these laws were intended to invite private foreign capital to be invested in projects which will contribute to the healthy development of Indonesia's economy. Pursuant to the law on industrial affairs, selection and transfer of foreign industrial technology which is strategic in nature and needed for the development of domestic industry. On the other hand, as indicated above that the licence agreement between the parties concerned must be reduced to the form

\footnotetext{
${ }^{14}$ See Article 8 of the Presidential Decree No. 75 of 1955.

${ }^{15}$ See Minister of Manpower Regulation No. 143 A/MEN/1991 on Educational and Training Obligatory Payments.

${ }^{16}$ See Article 12 of the Government Regulation No. 35 of 1994 regarding the Requirements and Guidelines of the Cooperation of Oil and Gas Production Sharing Contract.
} 
of a document embodying all the terms and conditions governing their rights and obligations, hence such document must be registered to the Directorate General of IPRs which shall be recorded and announced, with the payment of a fee. Where a licensing agreement is not recorded, said licensing agreement will not have legal effects on a third party. Otherwise, further provisions concerning licensing agreements shall be regulated by a Government Regulation. ${ }^{17}$ Unfortunately, at present, such Government Regulation is not enacted yet. It is mean, in this regard that the basic philosophy of the contractual arrangements i.e., TT from foreign companies to Indonesian nationals do not effective. ${ }^{18}$

\section{The Role of Indonesian Government for Technology Transfer}

The primary objective of a licensee in entering into a technology licence agreement includes the acquisition of a developed and tested industrial process without having to bear the risks, delay and expense of its development. For licensees in DCs, the unavailability of facilities or resources for research and development $(R \& D)$ often renders the licensing of foreign technology rights the only means of obtaining them. Even if the licensee were to embark upon the necessary research, the risk of failure is compounded by the risk that a rival enterprise may be able to obtain industrial property protection in relation to the relevant technology. 'Licensing in' may assist a licensee after a profitable exploitation period, under the name or mark of the licensor, to aggregate the financial, technical and commercial means necessary to initiate its own research programme.

In Indonesia a major 'unpackaged' (non-equity) mode of TT from advanced country firms to Indonesian firms has been technical licensing agreements (TLAs). Although no quantitative data are available on the number of these TLAs ${ }^{19}$,

\footnotetext{
${ }^{17}$ See Article 73 of the Patents Law, 2001.

${ }^{18}$ Interview's result with the Directorate General of IPRs (Dirjen HAKI), Jakarta, 02 March 2006, viz: "In so far, all parts of the IP legislation promise more detailed guidelines to be issued as part of Government Regulations or Presidential Decrees. The problem here is that 'none of these guidelines has so far been issued'. Implementing provisions for licensing registration are not among those provisions that the government is currently working on. As a consequence, practitioners in Indonesia have had to experience that the Directorate General of IPRs rejected the registration of patent licensing agreements because the applications could not be processed without those guidelines. Under these circumstances, licensing agreements can be concluded, but not be registered and as a consequence, they have no legal effect vis-à-vis third parties.

${ }^{19}$ In so far, all parts of the IP legislation promise more detailed guidelines to be issued as part of Government Regulations or Presidential Decrees. The problem here is that 'none of these guidelines has so far been
} 
circumstantial evidence indicates that these TLAs often involve the transfer of older and mature technologies thatdo not offer the recipient country a long-term competitive advantage in the global market. ${ }^{20}$ However, for a late-industrialising economy like Indonesia, acquiring and mastering these older technologies first is a good way to develop the important basic industrial technological capabilities (ITCs), namely the production, investment and adaptive capabilities. In this regard Marks, viewed as follows:

"Unlike the other three ASEAN countries, Malaysia, the Philippines, and Thailand, Indonesia does not have data on the number of technology licensing agreements signed by Indonesian firms (including both domestic firms without foreign equity ownership and joint ventures with foreign investors) with their foreign licensors. Nor is there a single satisfactory definition of technology inflows, especially concerning the transfer of human capital resources. But as an approximation one can use data on royalty and licensing payments to the major technology suppliers in the Asia-Pacific region, namely the U.S. and $J{ }^{21}$. For instance, in a publication of Japan's Agency of Industrial Science and Technology published in 1992 it was mentioned that out of Japan's total technology exports of yen 339.4 billion during fiscal 1990, 5.8 per cent of this total amount (yen 19.7 billion) went to Indonesia".22

Imports of capital goods provide another way of acquiring the means of production without the transactional costs involved in FDI or TLAs. Capital goods imports are actually embodied technology flows entering a country. They introduce into the production processes new machinery, other capital equipment and

issued'. For detailed see note 18 above, as well as for more comprehensive, see Abd Thalib's Ph. D. Thesis, "PEMINDAHAN TEKNOLOGI DI INDONESLA: KAJLAN PERUNDANGAN" (non-publication), Fakulti Undang Undang University of Malaya, 2012. In this context, see Indonesian Patents Act, 2001 such as: Article 70: "Unless agreed otherwise, a patent holder shall continue to be able to personally exploit the invention or to grant a license to any other third party to perform acts as referred to in Article 16"; Article 71: "(1) A licensing agreement shall be prohibited to contain provisions that may directly or indirectly give rise to effects which damage the Indonesian economy, or to contain restrictions which obstruct the ability of the Indonesian people to master and develop technology in general and in connection with the patented invention in particular. (2) The Directorate General shall refuse any request for registration of a licensing agreement containing provisions as referred to in paragraph (1)"; Article 72: "A licensing agreement shall be recorded and announced, with the payment of a fee. (2) Where a licensing agreement is not recorded at the Directorate General as referred to in paragraph (1), said licensing agreement will not have legal effects on a third party"; Article 73: "Further provisions concerning licensing agreements shall be regulated by a Government Regulation".

${ }^{20}$ Marks, Stephen, 1999, Foreign Direct Investment in Indonesia and its Management through Governmental Policy, Partnership for Economic Growth, Department for Industry and Trade, Jakarta, March, p. 6.

${ }^{21}$ See Hill, Hal \& Johns, Brian (1983), "The transfer of industrial technology to Western Pacific developing countries", Prometheus, Vol. 1, no. 1, June, p. 62.

${ }^{22}$ See, Agency of Industrial Science and Technology (1992), "Trends in Principal Indicators on Research and Development Activities in Japan", Technology Research and Information Division, General Coordination Department, Tokyo, p. 34. 
components that incorporate technologies which do not necessarily incorporate high or frontier technologies, but are nevertheless new to the recipient firm ${ }^{23}$.

These imported capital goods can be affordable way of developing local ITCs if they can be used as models for reverse engineering to produce the machines locally. However, Indonesian firms have in general not engaged in 'reverse engineering' on a large scale to develop their ITCs. However, capital goods imports also contain a significant disembodied element, as the foreign suppliers of these capital goods, specifically machinery, often send technical experts to Indonesian firms to train the workers of these firms how to operate, maintain and repair the imported machinery. This kind of technology and skill transfer by technical experts from foreign firms to Indonesian employees has been quite significant for most foreign machinery suppliers. This training is crucial as the mere imports of capital goods do not automatically lead to an enhancement of local ITCs, if local employees do not know how to operate, maintain or repair the imported machinery. However, if the imports of capital goods is accompanied by the effective training of local workers on how to operate, maintain and repair the imported machinery, these imports will lead to the development of the basic production (operational) capabilities of the firms and over time also to the development of adaptive capabilities, specifically to carry out minor process adaptations. ${ }^{24}$

In this regard, as far as TT in Indonesia is concerned Kuroda ${ }^{25}$ pointed out:

"A thorough examination of the extent to which technology transfers actually take place presupposes a clarification of terminology. In the most general sense of the word, 'technology' is a system of production in which inputs are transformed into outputs. It includes specifications of inputs, outputs and organizational arrangements. Productive activities may are of three types: operations, improvement and innovation. The latter two can refer to both processes and products. Taken together they convey technical change an especially important form of improvement is adaptation to local conditions. Not allimported technologies are equally suited for implementation in a developing country such as Indonesia. This study therefore implicitly also addresses the question whether technologies transferred through Japanese investment are indeed the most appropriate ones for Indonesia. Transfers of

${ }^{23}$ See, Soesastro, Hadi, "Emerging Patterns of Technology Flows in the Asia-Pacific Region; The Relevance to Indonesia", in: Hill \& Thee (editors), 1998, p. 304.

${ }^{24}$ See, Thee Kian Wie, "The Major Channels of International Technology Transfer to Indonesia: An Assessment", in: Journal of the Asia-Pacific Economy, Vol. 10, no. 2, 2005, pp. 214-36.

${ }^{25}$ See, Kuroda Akira, "Technology Transfer in Asia. A Case Study of Auto Parts and Electrical Parts Industries in Thailand”. Tokyo: Maruzen Planet, 2001, pp. 38-39, 186. 
technology may prove ineffective precisely because not the right kind of technology was chosen in the first place or because local absorptive capacities were inadequate".

The success of an international TT is measured by the extent to which Indonesian nationals have achieved technological capability so that they can use imported or transferred technology efficiently. It is useful to distinguish between four types of industrial technological mastery:26 (1) Acquisitive capability, i.e. knowledge and skills required to search, assess, negotiate and procure relevant foreign technologies as well as to install and start up the newly set-up production facilities. (2) Operational capability, i.e. knowledge and skills required for an efficient operation of the production process, including maintenance and repair of the machinery. (3) Adaptive capability, i.e. knowledge and skills required to carry out minor modifications of processes and/or products. (4) Innovative capability, i.e. knowledge and skills needed to carry out research and development (R\&D) in order to make major changes in process and/or product technologies".

The effectiveness of technology transfers is measured by scores on the development of each of these capabilities. Much of the literature applies a rather narrow conception of TT stressing the actual transmission of skills from one individual to another. This is accomplished through training, both formal and nonformal, as well as through participation and observation while working in a foreign-controlled firm. Chief channels for such transfers are foreign direct investment and technical assistance programs under the auspices of official aid. Such a narrow conception of TT has an important shortcoming as it leaves out the absorption of foreign technologies through technical licensing or use of imported machinery and equipment. In either case, there need not be any foreign equity participation or direct foreign involvement with the firm in question. A broader conception of TT should incorporate also the absorption on the level of the individual firm and the diffusion of imported technology throughout industries.

${ }^{26}$ See, Sripaipan Chatr (1990)i, 'The Acquisition of Technological Capabilities by Thai Manufacturing Firms', TDRI Newsletter [Bangkok: Thailand Development Research Institute] 5 (3), pp. 6-11. For a slightly different formulation (acquisition - development - utilization - maintenance) see Prayoon Shiowattana, 'Technology Transfer in Thailand's Electronics Industry', in: Yamashita Shoichi (ed.), Transfer of Japanese Technology and Management to the ASEAN Countries,: University of Tokyo Press, Tokyo, 1991, pp. 169-193. 
Both in turn are highly dependent on conditions in the receiving country, especially with regard to economic incentives and human resource development.

\section{Chinese Regulations}

\section{Patent Law of the People's Republic of China 2008-12-27}

To make the Patent Law in compliance with the TRIPS Agreement, the Patent Law was revised to grant patentee the right to prevent others from "offering for sale" patented products or products obtained directly by patented processes. In the revised Patent Law, Article 11 reads:

"after the grant of the patent right for an invention or utility model, except as otherwise provided for in the law, no entity or individual may, without the authorization of the patentee, implement the patent, namely make, use, offer for sale, sell or import the patented product; or use the patented process, or use, offer for sale, sell or import the product directly obtained by the patented process, for production or business purposes."

The patent owner is granted the exclusive right to prevent others from making, using, offering for sale, or selling the patented invention. Prior to the Agreement on Trade-Related Aspects of Intellectual Property (TRIPS) accompanying the Uruguay Round GATT, patents were issued for a nonrenewable period of seventeen years, measured from the date of issuance. Under current statutory provisions, the term of protection for utility patents is twenty years measured from the date of filing, ${ }^{27}$ with extensions of up to five years permitted for drugs, medical devices, and additives. The current term of protection for design patents is fourteen years from the date of filing.

A long-established doctrine of patent law, the exhaustion doctrine, entitles a patentee to a single royalty per patented device. This rule aims to prevent patentees from collecting a series of royalty payments for a single invention. The Supreme Court affirmed this rule in its 1942 decision, United States v. Univis Lens Co., 316 U.S. 241. In 2008, the U.S. Supreme Court reconsidered the contemporary relevance of the doctrine inQuanta Computers v. LG Electronics (06-937). In a unanimous decision, the Court reaffirmed the doctrine, holding that the exhaustion doctrine prevents a

\footnotetext{
${ }^{27}$ See Article 42.
} 
patentee from bringing an action against a third party purchaser after having already received a royalty payment from the initial sale. ${ }^{28}$

\section{Regulations for Technology Transfer}

Today this entry is dedicated to TT, and Import of IPRs. This theme is of paramount importance especially today if a foreign enterprise decide to make use of its intangible assets like IPR to do business in China.The TT or intellectual and industrial property rights (e.g., trademarks, patents, know-how) represent the most frequent contribution when setting-up a new business in conjunction with a Chinese counterpart or when forming others type of investments (e.g., FIE). Having analyzed in the precedent paragraphs the main characteristics of the IPRs directly involved in the realization of an investment in China, it is now necessary to spend a few words with regard to TT or "import of IPRs into China."

(The rules governing the TT has changed with the accession of China into the WTO. The regulatory instrument currently in force and to consider on this question are: (i) le Regulation on Technology Import and Export Administration of the People's Republic of China, promulgated by the State Council and come into force January 1, 2002; (ii) Administrative Measures on Registration of Technology Import and Export Contracts, promulgated by the 'ex' MOFTEC now MOFCOM, December 30, 2001 in force January 1, 2002; (iii) Administrative Measures on Import of Prohibited or Restricted Technology, promulgated by MOFCOM, as well as (iv) Administrative Measures for Export-Prohibited Technology or Export Restricted Technology).

The technology import and export as referred to in the Regulations on Technology Import and Export (2002) as "acts of transferring technology from outside the territory of the People's Republic of China into the territory of the People's Republic of China or vice-versa by way of trade, investment, or economic and technical cooperation."It seems appropriate to specify that the Regulations 2002 have a rather broad concept of "technology," and in particular refers to "TT" as the assignment or use of patents or models in China by a third party helping the foreign owner of these rights to achieve certain goals; or also refers to the supply of know-

${ }^{28}$ See Legal Information Institute (LII), is available at:https://www.law.cornell.edu/wex/patent,accessed on, 12 December 2015. 
how in the form of technical information, drawings or other material containing information on manufacturing processes, formulas, designs of products; or even as the supply of facilities or production lines, when it involves the sale or the right to use patents.In other words, the "technology" essentially refers to the complex technical knowledge, experiences, formulas, designs, of which the company owns and uses in a given production process or other industrial process. In general these are intangible assets protected as industrial property rights (a category of IPRs) which naturally belong to the company's assets.

\section{The Role of Chinese Government for Technology Transfer}

Under the TT Regulations 2002, technology is divided into three categories: (i) freely transferable, (ii) restricted and (iii) prohibited technology. The category under which a particular technology falls, depends on whether it is for import or export; therefore a technology that might be prohibited from import might at the same time be free for export.

Technology classified as prohibited from import may not be imported; restricted technologies require approval from the Ministry of Commerce (MofCOM) and the Ministry of Science and Technology before the TT contract is enforceable; and freely transferable TT contracts require registration (rather than approval) with MofCOM (or its local branch) but are still effective upon proper execution. However, certain restrictions are prohibited as a matter of public policy and certain unreasonable restrictions on the transferee's use of the technology in cross-border transfer contracts can be held invalid.

Contracts involving "TT," when the transfer is seen and considered as a "capital contribution" in the case of the creation of an FIE, must always be approved in accordance with the procedure for authorizing the investment made regardless of the type or category of technology involved. The registration authority (the MofCOM) may require an agreement to be amended before registration, if certain restrictive clauses are included. The Contract Law stipulates that a technologyrelated contract which illegally monopolizes technology, impedes technological advancement or infringes another's technology is invalid. 
Terms that restrict one party from obtaining from other origins technology similar to or in competition with the technology transferred is prohibited. Terms must not require the transferee to accept conditions that are dispensable to the technology import, such as purchasing unnecessary technology, raw materials, products, equipment or services. Requiring the transferee to pay royalties or assume certain obligations for using technologies of expired or invalid patents is prohibited.

In addition, the "transfer" can take place according to different types of contract, often through licensing agreements, with which the owner of these intangible assets (e.g., patents, know-how) grants the right to use them.The registration of the contract or of the license of technology is a common practice and is used not only to carry out a formal control on the content of the contracts, but also in order to "standardize" the administration of contracts for import and export of technologies.

If during the audit, authority finds that the technology to be transferred is obsolete, or that it is already available in China, or considers that the fees are excessive, or that some clauses penalize a party, it can refuse to register the contract. In such a case, the parties are required to change their agreement and re-submit the contract to the MofCOM; in fact, registration is usually a necessary condition for the licensee to make use of the rights as stipulated in the contract, and to pay the royalties due, or to take advantage of any tax relief.

The dispositions for the registration of the contracts, and the limits concerning the content, are contained in both the Administrative Measures on Registration of Technology Import and Export Contracts and in the Administrative Measures on Import of Prohibited or Restricted Technology; reference must also be done to the Administrative Measures for Export-Prohibited Technology or Export Restricted Technology. All these regulations have a role to play in this context, and they have to be considered together.

In licensing core technology in inter-company transfers, the licensor would unlikely restrict the subsidiary from making improvements. However, headquarters may require that it exclusively own, jointly own, obtain an assignment, or use for free the improvements made by the licensee based on the 
licensed technology. These restrictions raise monopoly concerns and are considered to impede technological advancement. Restrictive clauses such as these are prohibited if there is no reasonable consideration given in return. That is, there must be reciprocity.

\section{Conclusion}

As we have seen above, nor Indonesian patents system, neither the role of government efective for the TT in Indonesia. At present, as far as TT is concerned, no specific regulations on the TT have been issued. Some policies conflict with each other. Some are geared to meeting the needs of special sections of industry, while others are deficient in addressing the needs they are supposed to meet. Responsibility for policies is spread over different agencies, with little effective coordination, and sometimes active rivalry. "The pattern of inward technology flows for Indonesia seems to be dominated by the use of FDI as the main channel for technology acquisition. In some sense this has been the country's implicit 'technology policy', and the favourable attitude of the government towards FDI has been based to a large extent on the promise of technology that will be brought in as part of the investment package. The government has attempted to use some performance requirements in its foreign investment regulations to effect more rapid transfers of technology. The regulations have been weak or have not enforced, and no specific incentives have been given to encourage FDI that will upgrade local technological capabilities".Further, as far as TT is concern,any technology transfers involving PRC patents (including contracts transferring an inventor's right to apply for a patent registration in China) must in addition be registered with the State Bureau of IP or its local counterparts within three months of the contract's effective date. Proper registration of a patent license is also a prerequisite for foreign exchange remittance (along with any technology import contract approval).

Legally speaking, TT contracts involving restricted technology will not take legal effect until approved by the competent authority. In other words, if the transferee in an unapproved contract chooses to stop paying the transferor after having already received confidential know-how, IPRs and other useful materials, 
the transferor could face a lengthy and uphill legal proceedings to enforce its IPRs. Practically speaking, perhaps the most powerful enforcement tool for the TT administration regime, at least for technology import contracts, is China's strict foreign exchange control policy. Under the regulations, evidence that a technology import contract has been properly approved or registered is strictly required to facilitate the remittance overseas of royalties and other payments under technology import contracts. In other words, if the requisite formalities have not been completed, the foreign transferor cannot receive its payments. Other violations of the import or export restrictions under the new regime may expose the contracting parties to broad-ranging legal consequences, ranging from a warning for technical violations to possible criminal penalties for exportation of prohibited technologies. However, as the relevant penalties provisions are quite vague, it is unclear how the new regime will be effectively enforced for contracts, which requires neither approval for effectiveness nor payments overseas.

There have been calls for government regulation of TT agreements on the grounds that foreign licensors (technology suppliers) may impose 'unfair' restrictions and conditions in such agreements. Hence, government intervention could increase the bargaining power of the local recipients (the Indonesian firms) in their negotiations with the prospective technology suppliers (the foreign firms), like Chinese government has succeeded.

Despite these suggestions, successive Indonesian governments have thus far not indicated any interest in changing the country's liberal technology import regime. There are strong arguments for continuing this stance, as government intervention in negotiations between prospective foreign technology suppliers and Indonesian technology buyers, particularly by attempting to eliminate or reduce what it perceives to be unduly restrictive conditions in technology licensing agreements, might very well slow down the inflow of new FDI, and the accompanying important inflow of technology imports, particularly now that new FDI inflows and the related technology inflows are needed more than ever to revive the Indonesian economy. 


\section{Bibliography}

\section{Books}

Agency of Industrial Science and Technology, "Trends in Principal Indicators on Research and Development Activities in Japan", Technology Research and Information Division, General Coordination Department, Tokyo, 1992.

Gerschenkron, A., Economic backwardness in historical perspective: a book of essays, Belknap Press of Harvard University Press, 1962.

Kuroda Akira, "Technology Transfer in Asia. A Case Study of Auto Parts and Electrical Parts Industries in Thailand". Tokyo: Maruzen Planet, 2001.

Marks, Stephen, Foreign Direct Investment in Indonesia and its Management through Governmental Policy, Partnership for Economic Growth, Department for Industry and Trade, Jakarta, March, 1999.

Nakamura Keisuke and Padang Wicaksono, "Toyota in Indonesia. A Case Study on the Transfer of the TPS", Jakarta: Center for Japanese Studies, University of Indonesia, 1999.

Ocampo, J.A. \& Vos, R., Uneven economic development, United Nations Publications, 2009.

Ocampo, J.A., Sundaram, J.K. \& Khan, S, Policy matters: economic and social policies to sustain equitable development, Zed Books, 2007.

P. Gehl Sampath, P. Roffe- Unpacking the International Technology Transfer Debate: Fifty Years and Beyond, International Centre for Trade and Sustainable Development (ICTSD), Issue Paper No. 36, International Environment House 2, 7 Chemin de Balexert, 1219 Geneva, Switzerland, 2012.

Rosenberg, N, Inside The Black Box, Technology and economics, Cambridge University Press, 1983.

S. Gautama and R. Winata, "Hak Atas Kekayaan Intelektual (HAKI): Peraturan Baru Desain Industri" (Intellectual Property Rights (HAKI): New Regulations on Industrial Designs), Penerbit PT. Citra Aditya Bakti, Bandung, 2000.

Sjöholm, Fredrik, 'Joint Ventures, Technology Transfer and Spillovers: Evidence from Indonesian Establishment Data', paper presented at the Second International Symposium on Foreign Direct Investment in East Asia, Tokyo, 1998.

Soesastro, Hadi, "Emerging Patterns of Technology Flows in the Asia-Pacific Region; The Relevance to Indonesia", in: Hill \& Thee (editors), 1998.

Sripaipan Chatr,'The Acquisition of Technological Capabilities by Thai Manufacturing Firms', TDRI Newsletter [Bangkok: Thailand Development Research Institute] 5 (3), 1990. 
Stephen P. Ladas, "Patents, Trademarks and Related Rights: National and International Protection", Harvard University Press, Cambridge, 1975.

, 'Technology Transfer from Japan to Indonesia', in: Yamada Keiji (ed.), The Transfer of Science and Technology between Europe and Asia, 1780-1880 (Kyoto: International Research Center for Japanese Studies), 1994.

'Indonesia: Technology Transfer in the Manufacturing Industry', in: Hadi Soesastro and Mari Pangestu (eds), Technological Challenge in the Asia-Pacific Economy (Sydney: Allen \& Unwin), 1990.

Thee Kian Wie and Mari Pangestu, 'Technological Capabilities and Indonesia's Manufactured Exports', in: D. Ernst, L. Ganiatsos and T. Mytelka (eds), Technological Capabilities and Export Success in Asia (London/New York: Routledge), 1998.

World Bank, The East Asian Miracle: Economic Growth and Public Policy. Washington, DC, November, 1993.

Yamashita Shoichi (ed.), Transfer of Japanese Technology and Management to the ASEAN Countries (Tokyo: University of Tokyo Press), 1993.

\section{Journals/News Paper}

Hill, Hal \& Johns, Brian (1983), "The transfer of industrial technology to Western Pacific developing countries", Prometheus, Vol. 1, no. 1, June.

Jakarta Post, 11 June 1997.

Thee KianWie (2005), “The Major Channels of International Technology Transfer to Indonesia: An Assessment", in: Journal of the Asia-Pacific Economy, Vol. 10, no. 2 .

Legal Information Institute (LII), is available at: https://www.law.cornell.edu/wex/patent, accessed on, 12 December 2015.

\section{Statutes / Government Regulations}

Indonesian Patents Law, No. 14 of 2001.

Indonesian Investment Law, No. 25 of 2007.

Indonesian Oil and Gas Law, No. 22 of 2001.

Patent Law of the People's Republic of China 2008-12-27.

Government Regulation No. 35 of 1994 regarding the Requirements and Guidelines of the Cooperation of Oil and Gas Production Sharing Contract.

Regulation on Technology Import and Export Administration of the People's Republic of China, promulgated by the State Council and come into force January 1, 2002 
Administrative Measures on Registration of Technology Import and Export Contracts, promulgated by the 'ex' MOFTEC now MOFCOM, December 30, 2001 in force January 1, 2002.

Administrative Measures on Import of Prohibited or Restricted Technology, promulgated by MOFCOM.

Administrative Measures for Export-Prohibited Technology or Export Restricted Technology).

Minister of Manpower Regulation No. 143 A/MEN/1991 on Educational and Training Obligatory Payments. 